\title{
Rethinking the modernity of Bernanos: a Girardian perspective
}

\begin{abstract}
The critical consensus about the modernity of Georges Bernanos's political writings is too dependent on hegemonic social and cultural theories. While Pierrette Renard's long essay on Bernanos rightly identifies his stylistic modernity, it wrongly depicts his polemical work as a search for nostalgic analgesia and as a statement of quasi-Nietzschean revolt. Sven Storelv's attempt to reread Bernanos's polemical works by relating them to the Book of Revelation is not substantiated by his evidence, but still highlights key Bernanosian themes which can be found systematically related in the theoretical oeuvre of René Girard. Analysis of Bernanos's Scandale de la vérité, Nous autres Français and Les Enfants humiliés in this light reveals in fact the links that Bernanos makes between imitation, desire, possessiveness and violence, and the myths that are generated to hide this process.
\end{abstract}

\section{Key words}

Bernanos, Girard, modernity, desire, violence, myth 
Since the 1990s there has been a broad critical consensus that the polemical writings of Georges Bernanos are paradoxically modern in substance and style. In his essay on Les Grands Cimetières sous la lune (1938), Bernanos's tract about the Spanish Civil War, Michel Estève (1994) underlines how Bernanos's dissent from the textbook Catholic response to the war was evidence of his affirming the primacy of conscience over ideology. Pierrette Renard (1998) has mounted the most complex and detailed argument in the secondary literature to demonstrate how Bernanos, in his polemical writings, was a moderne malgré lui. Most recently, Claire Daudin has sustained this critical tradition, arguing in Dieu a-t-il besoin de l'écrivain? (2009) that Bernanos's personal faith bespeaks no corporate allegiance to the Church. In keeping with the view that resistance to modernity is another manifestation of modernity, Bernanos has also been classed as one of the anarchistes de droite (Richard, 1988), alongside the likes of Léon Bloy or Louis-Ferdinand Céline. This approach depicts Bernanos as a child of the Belle Epoque who shared the violent scepticism of the antiEnlightenment about the Republican political project, but ploughed his own furrow in reacting against it. The work of all these critics is serious, profound and extensive. Moreover, a rapid survey of Bernanos's polemical writings, particularly from 1936 onwards, appears to corroborate their conclusions, especially when we consider how much Bernanos speaks about l'homme libre, or the extent to which he distances himself from the torchbearers of the antiEnlightement in the period of l'entre-deux-guerres, with the persistent exception of Edouard Drumont.

Still, even if the concept of Bernanos's modernity allows us to account for certain aspects of his writing, its counter-intuitive nature gives rise to the suspicion that its motives are far from disinterested. In spite of what critics have asserted about his pertinence to the young, there is no particular proclivity among French youth for the works or the views of Bernanos. Indeed, since French youth has shown itself persistently deaf to Bernanos's 
repeated appeals to its untainted idealism, and since many of the disputes in which Bernanos was involved are now long dead, one may legitimately wonder whether the critical framing of Bernanos as moderne is an attempt to proof his work against its creeping irrelevance. Otherwise, such rebranding smacks of a kind of well-intentioned but ideologically inspired gerrymandering to ensure clear ground appears between him and the accursed torchbearers of the anti-Lumières. Bernanos is one of us; he couldn't be one of them.

The starting point of this present investigation is that such an agenda of ideological sanitisation, combined with critical overdependence on the discourses of hegemonic social theory, has occluded important dynamics within Bernanos's political writings. Both have, for example, tended to obscure the fact that Bernanos's attacks on Franco's Spain or on the French right of the late 1930s, are rooted in an aversion to violently imposed social unity which also lies, paradoxically, at the root of Bernanos's contempt for contractual or democratic politics. They have likewise narrowed criticism's account of the paradoxes of Bernanos's Les Grands Cimetières sous la lune in which Bernanos, the right-wing Catholic and monarchist, embraces a modern conceptualisation of freedom - a position that this author has hitherto argued (Sudlow, 2003) - by taking sides against the nationalists during the Spanish Civil War

Now, it is also counter-intuitive to qualify contractual models of society as violent. Nevertheless, there are two reasons why it is pertinent to a discussion of Bernanos's polemical writings. First, as one who deprecates Enlightenment individualism, Bernanos deplores the radical autonomy of subjects who, from a contractual perspective, form a unity which can be coerced by the will of the majority. Bernanos's resistance to the democratic will cannot thus simply be reduced to the effects of extreme individualism. It is this paradox that descriptions of Bernanos as anarchist fail to account for. Second, as a moralist, Bernanos constantly eschews the appeal to abstract notions such as freedom of conscience, and engages 
instead in a process of myth-deconstruction by attacking the coercive agendas which political discourses of all shades seek to veil. Corralling Bernanos's analyses within the vocabulary of abstract moral discourse thus proves an obstacle to understanding the imaginative sensibilities and iconoclastic insights which underpin his frequent jeremiads. Those who plead in favour of a Bernanos moderne do so, therefore, at the cost of these distinctions.

Given these reservations about existing interpretations of Bernanos's political writings, the aim of this chapter is to challenge and enrich critical approaches to Bernanos's polemical work. To this end, it will first explore and assess in greater detail the widely accepted arguments in favour of the modernity of Bernanos's political writings. Then it will address Sven Storelv's analysis of Bernanos's polemical writings which breaks with the consensus that tries to define them in relation to modernity. Lastly, this chapter will consider the extent to which René Girard's mimetic theory provides a more useful tool than these other methods for understanding Bernanos's many complexities as an observer of French political life between the wars. For the purposes of this chapter, with its exploratory aims and its limited space, soundings of Bernanos's political writings will be restricted to Scandale de la vérité, Nous autres Français and Les Enfants humiliés, three tracts written after the Spanish Civil War but before the Blitzkrieg which the Germans launched against France in spring 1940. Forming a loose trilogy - 'trois oeuvres d'un seul tenant', as Jacqus Chabot has observed (1971: 536) - these texts represent the state of Bernanos's political témoignage on the eve of France's crushing defeat.

Prima facie, Girard's mimetic theory, which focuses on the relationship between desire, deceit and violence in literary, cultural, political and religious contexts, appears eminently suitable to rereading the writings of Bernanos, a figure often characterised as temperamentally violent, and who was preoccupied with violence throughout his writing career. This chapter will argue, however, that rather than being a pure agent of violence, 
Bernanos belongs to that tradition of writers who, according to Girard $(1961 ; 1972 ; 1982)$, expose the illusions and myths which veil mimetic desire and the violence it can unleash on the individual and societal levels. Thus this chapter will aim to resituate Bernanos's apparent anarchism and his belated disdain for Counter-Enlightenment figures in the context of his engagement with moral and cultural dynamics which would later become central to Girard's mimetic theory. In corroboration of our findings, we will also consider in the course of the analysis how Girard's last work, Achever Clausewitz (2007), strangely echoes some of the predictions of uncontrollable violence to be found in Bernanos's tracts. For it seems that what Girard has identified as an apocalyptic escalation of violence - la montée aux extrêmes was heralded already by Bernanos, caught between the horrors he witnessed in Majorca and the coming world war.

\section{Renard's Bernanos moderne and Storelv's Bernanos prophète}

The analysis and assessment of two key approaches to Bernanos's polemics will serve as a launching point for developing a new critical framework. The first approach is found in Renard's essay on Bernanos's modernity which stands as an exemplar of the critical consensus noted at the beginning of this article. The second is found in two essays by Sven Storelv who, by using the imagery of the Book of Revelation as a basis for his commentary on Bernanos's Essais et écrits de combat I, already foreshadows the Girardian analysis of Bernanos's polemical writings which this chapter will aim to elaborate further on.

\section{Renard}

Renard's essay in Etudes bernanosiennes 21 puts before us three principal arguments to sustain the critical depiction of Bernanos's modernity. First, Renard argues that his sense of the liquidation of the past and the disorientation this induces are signs that he feels the 
modern impossibility of integrating experience and knowledge (Renard, 1998: 82); second, she asserts that since Bernanos sees this disintegration as a negative thing, he assumes a constant attitude of combat against it, whence the habitual violence of his rhetoric, or his call to youth for a chivalrous ralliement, or his definition of prayer as revolt (Renard, 1998: 121); and third, she observes that Bernanos's modernity is further confirmed by his témoignage, the literary form that his combat assumes (Renard, 1998: 123-128). This is manifested, for Renard, in the freedom of criticism he exercises against the Church, and then in the blending of fiction and history in his last polemical works which, again according to Renard, show him retreating into a kind of subjective enclave to comment on events (Renard, 1998: 139). Renard's Bernanos finally embraces a kind of autonomy and interiority, and thus incoherently -though Renard would no doubt prefer paradoxically - Bernanos launches his attacks on modernity from the vantage point that modern subjectivity provides him with.

Despite the textual evidence which Renard marshals in favour of these arguments, they are problematic on several levels. The first argument alludes to the view which treats nostalgia as a manifestation of modern sensibility in flight from present incomprehension, a view also articulated by David Lowenthal (1985). Yet this is unconvincing in the case of Bernanos who finds experience and knowledge difficult to reconcile but not impossible. Indeed, since he is firmly convinced that their reconciliation can be found at the highpoint of Chrétienté in the Middle Ages, his analysis of modernity does not plunge itself into the past by way of analgesic nostalgia, but rather by way of preparing the past's retrieval. In this respect a second problem with Renard's analysis concerns its assumption that the retrieval of the past can only be an exercise in nostalgia pitched against the exorable linearity of time. It can be argued, however, that writers whose imaginative formation has been liturgical and sacramental (Greeley, 2001) — and this was indeed the case for Bernanos not only as a Catholic but as a pupil in a minor seminary during the early years of the liturgical movement 
in France - envisage the past in ways that are meta-chronological because ultimately eschatological. Renard's implication that Bernanos's call for a renewal of the chevalerie de la Chrétienté is a nostalgic and pantomimic performance, undertaken to counter his disorientation, thus fails to consider how the liturgy, a central process in the formation of Catholic sensibility and imagination, could provide a model for the imaginative reactualisation in the present of something that happened in the past.

Renard's second argument about Bernanos's combat as the response to his modern disorientation also poses problems. Renard claims that Bernanos forms part of the tradition whose fulminating heralds include Baudelaire and Nietzsche, and which condemns the world — Renard recapitulates Nietzsche's words - as 'impie, immoral, inhumain' (Renard, 1998: 76). Yet we would be mistaken if we failed to appreciate in Bernanos's rhetoric against his enemies the wounding of a more fundamental desire for reconciliation. Bernanos's wellknown inclination to fall out with his contemporaries was countered by an instinctive readiness to bury the hatchet, as he did with Jacques Maritain (though not successfully with Charles Maurras). Given Bernanos's literary filiation to Léon Bloy, in both theme and language (Milner, 1967: 55), Bernanos's fulminations against his enemies can arguably be read in the light of Bloy's conclusion to his own Exegèse des lieux communs which, after excoriating all the axioms of bourgeois sensibility, concludes with this disarming appeal: 'Il faudrait pourtant y songer, pauvre imbécile, et en y songeant, s'arrêter un peu d'être stupide et de faire souffrir les malheureux. Car nous sommes cela, toi et moi, et rien que cela, des abîmes!' (p. 306). The combat of Bernanos and Bloy is not a revolt against perpetual incomprehension, or a statement of never-ending hostility, but most often a corollary of their belief in the possibility of eventual reconciliation. 'A la douce pitié de Dieu', Bernanos writes to Maurras in his last letter to him on 21 May 1932 (1971: 1258) since for Bernanos there is reconciliation in no other locus. To return to the theme of combat, while it is also true that 
Bernanos defines prayer as revolt - 'la seule révolte qui se [tient] debout' (1971 [1938]: 364) - we would be mistaken to assume that this is simply an affirmation of raw human agency or a spiritual variation on what was fundamentally a political agenda. Bernanosian prayer stands upright because it is a theocentric movement. Indeed, it is only when the prayer of Bernanos's fictional saints renounces anthropocentrism and the maximalisation of human agency that it can avoid being disintegrating; as the last page of the Journal d'un curé de campagne notes, 'il est plus facile que l'on croit de se haïr; la grace est de s'oublier' (Bernanos, 1961 [1936], 1258).

Renard's view that the increasing interiority of Bernanos's works is a sign of modernity is much better founded, though lacking in certain essential nuances. In the polemical works, especially the late ones, Bernanos' témoignage is certainly marked by the predominance of '[le] regard, le role de l'expérience, l'importance du present et de la raison, l'utilisation, en fait, de la méthode des Lumières' (Renard, 1998: 139). Yet here, Renard arrives at her conclusion - la methode des Lumières - with undue haste. The tendencies which she identifies in Bernanos's writings might equally be clarified by drawing on Charles Taylor's distinction between the 'porous' and the 'buffered individual'. In his monumental opus A Secular Age (2007: 37-41) Taylor posits a distinction between the pre-modern individual, who is porous with respect to the meaning and purpose of the world insofar as they are exogenous to his consciousness; and the buffered individual, who constructs that meaning and purpose from the inside out or endogenously. Still, Taylor maintains, there is a porous or open version of buffered individuality - an open immanence - which, while conscious of its own psychological egocentricity, is open to an exogenously located meaning and purpose in a world created by a divine subject. This latter kind of interiority, if it is buffered in its internal dynamics, is nevertheless porous in its fundamental assumptions. 
While Bernanos, therefore, retreats further and further inside himself in his polemical works, mixing historical commentary with fictional or even fable-like representations of moral questions, why should we conclude that he is embracing les Lumières given that he remains nevertheless convinced of, and attached to, a world of universally valid meanings and purposes which only porosity to the divine make available to him? After all, in spite of his great rage at injustice and weakness among the clergy, Bernanos does not become a religious sceptic. Neither does he adopt an anthropocentric view of the problems that beset the public arena; on the contrary Bernanos constantly answers the question of humanity by posing again and again the question of God. It is in fact only his belief in some universally valid reality beyond the material world that makes it possible for Bernanos to s'oublier, to forget himself. Now, this is of critical importance since it demonstrates that Bernanos's coordinates are not simply those required by the need to contest the modernity that surrounds him. There is all the difference in the world - and not simply a difference à rebours between ineluctable immanence and an immanence open to that which is without. If this is $l a$ methode des Lumières, then it is - pace Renard - strangely hostile to the scepticism and unbelief that the Lumières intended to herald.

Renard's view of Bernanos's modernity appears to be influenced by an overdependence on hegemonic social and cultural theories, as do the views of other likeminded critics. For her, it is necessary to locate Bernanos on this terrain of the Lumières, even when such conclusions run counter to what we know to have been Bernanos's most enduring tendencies. Even if, to the extent that his thinking displays the characteristics of Taylorian open immanence, we recognise Bernanos's stylistic tendencies as modern, we can still ask whether Renard coherently frames Bernanos's work by making it so utterly dependent on the very ideological hegemony which he deplored. While such an analysis 
could account for the reactionary characteristics of Bernanos's polemical work, it appears to end in a paradox which is itself more stylistic than substantive.

\section{Storelv}

A more convincing account of Bernanos's political works, and one which dissents from the consensus about his modernity, can be found in the work of Norwegian critic Sven Storelv. In his essays 'Remarques sur le mythe du déclin du monde' (1993 [1972]) and 'Bernanos, Discours pamphlétaire et discours apocalyptique' (1993 [1987]), Storelv argues that analysis of the Essais et écrits de combat I, the first volume of the Pléiade edition of Bernanos's political writings, could usefully begin by considering Bernanos's imaginative preoccupation with les puissances du Mal. This preoccupation, which is sometimes advanced as a reason to classify Bernanos's view of evil as Manichean, is attributed by Storelv to the influence of The Book of Revelation on Bernanos's thought. In the first of these essays Storelv criticises Magdalena Padberg's thesis Das Romanwerk von Georges Bernanos als Vision des Untergangs, which, he says, obscures the prophetic character of Bernanos's fictional work by restricting the meaning of myth to pure fable. By way of developing a prophetic reading of Bernanos's fictional work, Storelv then develops the parallels between it and the Book of Revelation, notably with regard to its imagery of the natural world, the signs of coming destruction and the demonic (1993 [1972]): 128).

His conclusion that Bernanos appropriates the language and themes of the biblical prophetical tradition is furthered in his second essay 'Bernanos, Discours pamphlétaire et discours apocalyptique' (1993 [1987]), in which he develops two pieces of evidence to corroborate the parallels between Bernanos's writings and the Book of Revelation. The first is Bernanos's favoured depiction of the devil as the ape of God, the imitator or mimic, whose mimesis of the divine is an invitation to idolatry, and an explanation of the devil's hostility to 
God. The second is the subsequent impostures by which this hostility is concealed. These two beasts — idolatry and imposture — are, according to Storelv, the very puissances $d u$ Mal that Bernanos never ceases to denounce. For Storelv, therefore, it is not modernity or the Lumières which allow us to account for the paradoxes and power of Bernanos's polemical writings. Rather, it is the nexus of idolatry and imposture, derived from the Book of Revelation, which is 'le noyau de base irradiant qui règle le jeu des significations de tous les écrits de combat' (Storelv, 1993 [1987]: 151).

While Storelv's analysis is stimulating, and certainly not dependent on a counterintuitive classification of Bernanos as moderne, textual evidence for Bernanos's reliance on the Book of Revelation is not abundant. In the first of these essays, Storelv provides only one substantial textual reference from the Book of Revelation (referring to Chapter 13 and the two beasts), and in the second essay there are none. Storelv also appears to depict the biblical prophetic tradition as unproblematic, even though the Book of Revelation is a notoriously dense and multilayered text which has posed many problems for biblical hermeneutics (Callows, Kovacs and Rowland, 2004: 13-38). The centrality Storelv accords to The Book of Revelation in Bernanos's imagination also leads to its own hermeneutic problems. In one instance he associates the image of the dragon, mentioned once in Nouvelle Histoire de Mouchette (1961 [1937]: 1276), with the dragon of Revelation, but ignores the fact that, for example, there are potentially far more classical than biblical sources for Jambe-de-Laine's wild, snorting horse in Monsieur Ouine (1961 [1946]: 1360-1361).

In spite of these issues, Storelv's analysis provides fruitful categories in which to approach Bernanos's work, especially given the recurrence of the problems of truth, deceit, masquerade and imitation in Bernanos's polemical writings. Most importantly, Storelv's analysis foregrounds not the thematic preoccupations of Bernanos's writing - unlike much Bernanosian criticism which has focused relentlessly on themes such as holiness, priesthood, 
childhood or evil - but rather the discursive mechanisms which drive it forward. Now, if Storelv fails to root these dimensions of Bernanos's writings convincingly in the Book of Revelation, they can in fact be found linked systemically in the later work of cultural anthropologist René Girard who conceptualises the processes of mimetic behaviour (with which we can associate idolatry and the monde à rebours) and myth (with which we can associate imposture) as key drivers of human conduct and human cohesion.

The usefulness of a Girardian reading of Bernanos suggests itself immediately with respect to Renard's claim that Bernanos's attack on the Spanish nationalists and on the Church in Majorca was effectively a paradoxical statement of Bernanos's belief in freedom of conscience. From a Girardian perspective we need reach no such conclusion. In Girardian anthropology, the cohesion of a community, regardless of culture, is always the result of a process in which the build up of violence, induced by duelling desires, is relieved through the persecution of a scapegoat who is both innocent (because it has done nothing wrong) and guilty (because its persecution can somehow forge cohesion anew). The contribution of Christianity to this process, says Girard (2007 [1978]), has been to declare the total innocence of the scapegoat, and to posit renunciation or love as the cure for duelling desires. Reread in this light, Bernanos's preoccupation in Les Grands Cimetières sous la lune (which then hangs over Scandale de la vérité, Nous autres Français and Les Enfants humiliés) is not freedom of conscience or the emancipation of the individual — ethical principles of a world view which Bernanos found abhorrent in any case — so much as the relentless declaration of the innocence of those who were murdered by the Spanish nationalists in Majorca. Saving the honour of honour, Bernanos's stated aim in Scandale de la vérité, is tied implicitly to his repeated attempts to save the innocence of the Majorcan innocents, and more tangibly, to denounce their persecutors and all the myths invented to disguise the latter's guilt. 


\section{A Girardian Reading of Bernanos}

There is no immediate reason to label the declaration of innocence as a particularly Girardian instinct avant la lettre. After all, Bernanos's concern with innocence made little difference to his obstinate lifelong anti-Dreyfusardism. Moreover, the stylistically violent polemics for which Bernanos would become well known, notably through Les Grands Cimetières sous la lune and his radio speeches during the Second World War, might from a Girardian perspective be thought to make him insensitive to the processes that generate and disguise violence.

Quite the contrary is true, however. The Girardian resonances of Bernanos's polemical writings are seen in his growing sensitivity, from the mid-1930s onwards, first, to the escalation of violence (a violence induced by imitation) and, second, to the power of myth. In Girardian theory violence emerges from the rivalry created by desire. For Girard (1962), desire is always something imitative. The desire of the subject is not a binary relationship with an object (as it was for the Romantic tradition), but arises by a kind of triangulation when the subject learns the desirability of the object from the desire of another subject or model for the same object. In primitive societies the rivalry and violence that grew out of these competing desires - and which would reach its crisis when the rivalry and not the object had become thematic — had to be controlled by various social mechanisms (such as taboos) but, argues Girard (1972), when these were no longer sufficient, primitive societies always chose some scapegoat as a kind of safety valve to purge themselves of the accrual of violent tension. To retain the advantages achieved by the persecution of the scapegoat, the community needed to be protected from the truth of its actions by the generation of myths, traces of which Girard finds across all the cultures which he studies. Myth thus completes the violent cycle of desire, rivalry and mimetic crisis and at the same time perpetuates it by declaring falsely the guilt of the scapegoat and hiding the crimes of those guilty of violence. 
The possibility of a Girardian reading of Bernanos's polemical works in this chapter is made plausible by the correlations between the grandes axes of Girardian theory and the two poles of idolatry (denoting mimetism, rivalry and violence) and imposture, which Storelv identifies but does not ground adequately in his analysis. It is also rendered plausible by the critical work of Paul Delvaux (1988-89) who has long since pointed to tangible Girardian patterns in Bernanos's fictional writings. The correlations between dynamics in Bernanos's polemical writings and Girardian theory will be made clear in the analysis of Nous autres Français and Scandale de la vérité which follows. They will be corroborated but also brought into question by the subsequent analysis of Les Enfants humiliés, a text which contains all the elements Girard has identified as integral to the system of religious violence. Throughout, our findings will be illuminated by reference to Bernanos's perception of the escalation of violence and Girard's view, set out in Achever Clausewitz, that in the period of Western secularisation, when pagan and Christian mechanisms to control violence (respectively scapegoating, and renunciation and forgiveness) are much less readily available, there is bound to be a montée aux extrêmes in humanity's performance of violent rivalry. Indeed this was one of Bernanos's greatest preoccupations on the eve of the Second World War; knowing the capacity of humanity for violent rivalry, he feared the kind of war which modern humans would wage on each other. The implications of this montée are, however, apparent first in Bernanos's treatment of violence and of myth.

Violence and the 'montée aux extrêmes'

The composition of Nous autres Français was interrupted by that of Scandale de la vérité which was subsequently published first. Nous autres Français, like Scandale de la vérité and Les Enfants humiliés, is a series of reflections following no grand schema. A vague plan, nevertheless, emerges which sees the first four sections largely devoted to revisiting the 
errors of Charles Maurras and Action Française, and the last two sections describing and rehearsing the providential prince whom the royalist Bernanos believed France needed in her hour of crisis. Within this tract, therefore, we are constantly confronted by the contrast between the values of honour and truth, which such a prince represents to Bernanos's mind, and the violence and myth which he believes characterise the modern world and which are modelled by the Nazis and the Spanish Nationalists and epitomised by Maurrassian nostalgia.

To this end, for example, Bernanos distinguishes the violence of the Spanish nationalists or of the Nazis from his own arguably violent ideal of la chevalerie by noting their rage for conquest: 'les Bêtes déchaîneés, rugissantes, marchent sur les hommes' (1971 [1939b]: 659-660). Their taste for conflict is, he says, the sign of a fratricidal fury whose aims are in fact proprietary (Bernanos, 1971 [1939b]: 632). In other words, they conquer in order to possess. Here Bernanos anticipates a key Girardian theme: that violence results from the unsatisfied desire of the subject for the object possessed by another.

It is significant, therefore, in this regard that at the same time Bernanos denounces the unarmed ruse of the usurer against the poor as 'la forme la plus efficace de la force' (Bernanos, 1971 [1939b]: 633). Bernanos thus makes the link between the concupiscent pursuit of wealth (a key theme in his earlier tract La Grande Peur des bien-pensants) and the violence which it very often precipitates. While criticising the violence of totalitarianism, Bernanos maintains his contempt for the more subtle violence to be found under the conditions of political and economic liberalism. By corollary, Bernanos's concern for le pauvre can be read as a plea for the scapegoats of capitalism, and as an indictment of materialist, democratic society which he denounces at length in the conclusion to La Grande Peur des bien-pensants (1931: 314-350).

If such violence goes out in pursuit of the desirable, it emerges, for Bernanos, from the power of imitation. In the period before the Second World War, Bernanos's fear was that 
the French nationalists would rehearse against their compatriots, or against the Germans, the same insuperable pattern of hostility seen in Spain and which led to the themacity of violence in the crisis he witnessed in Majorca. Having once shared the anti-German discourse of the Right, he sees it now (without necessarily shedding it entirely) in relation to the violent ends which it serves: 'Bien avant le racisme de M. Goebbels, la mystique antiallemande avait sournoisement favorisé chez nous le concept d'une race allemande, d'une race damnée, taillable et corvéable à merci, indigne de pardon (Bernanos, 1971 [1939b]: 713).' Bernanos found in the rhetoric of the Right in 1939 a desire to see the Germans not merely defeated but made subject, and even excluded from reconciliation - indigne de pardon. In this respect Bernanos identifies the kind of oppressive rivalry which Girard will later class as that of 'monstrous doubles'. For Bernanos, at least in this case, the concept of race functions as a kind of mask which accords to one's adversary a monstrous character (Girard, 2008 [1972]: 248) and which justifies hostility against it.

If we pursue this Girardian line, it is striking that Girard's last book Achever Clausewitz sets out insights into violence which Bernanos again anticipates in Nous autres Français. The central thesis of Achever Clausewitz (2007: 62-64) is that without a scapegoat or without Christian renunciation, i.e. without the mechanisms which promise to solve violent tension, violence is likely to escalate inexorably in what Girard calls a montée aux extrêmes. Now Bernanos's appreciation of the scapegoat mechanism is implicit rather than explicit though it could be fruitful to look at figures like the two Mouchettes in that light — but in Nous autres Français he predicts this very escalation of violence in the context of the approaching war, especially in the minds of his erstwhile fellow militants from Action Française. The problem of Charles Maurras, says Bernanos, is that since he does not believe in the reign of God's grace, he prefers what Bernanos calls the precept of realism: 'Lorsque ton ennemi est étendu face contre terre, sans connaissance, ne perds pas l'occasion de lui 
écraser la nuque à coups de batons' (Bernanos, 1971 [1939b]: 713). Bernanos also notes Maurras's inconsistency in criticising the violence of others while quite unconsciously advocating violence to achieve his own ends. Thus, while Maurras excoriated the Germans for their policy of total war, he also applauded the bombings of Madrid and Barcelona (Bernanos, 1971 [1939b]: 654).

We will return to this process of self deception below since it is intrinsic to the myths that disguise violence. What is crucial here, however, is that, for Bernanos, the Maurrassian Right had lost the ability to draw a line in the sand between mercy and the iron law of justice, and thus had no means to oppose the mounting violence. From this perspective, the ironic rule of Action Française's strategy for restoring the monarchy par tous les moyens, même légaux finds its logical outcome in a violent hostility which is no longer a means but now an end in itself.

How did Bernanos come to perceive this danger of exponentially mounting violence? Precisely through his experience of the Spanish Civil War where he felt its logic had been played out perfectly. If we note that Maurras was ultimately in favour of Munich — surely evidence against the argument that Bernanos is pursuing — it is only right to point out his eagerness for rearmament against Germany before that time. We might label this opportunism rather than realism, but that aside, it is clear that Bernanos expected the very worst from the coming conflict, including the logical apogee of unbridled hostility in the kinds of extermination campaigns he had witnessed in Spain. There would be no easy limit on the coming violence; Bernanos thus foreshadows the Girardian montée aux extrêmes.

Storelv's first beast of idolatry is redolent of the mimesis and possessiveness which Bernanos describes, but fails to capture fully the links which Bernanos perceives between desire, possessiveness and violent hostility to the adversary. For Bernanos, as for Girard, however, the driving force behind so many events is unregulated, imitative desire which 
always threatens to explode into uncontrollable violence. That Bernanos is opposed to the violence of liberal capitalism and political totalitarianism shows that his position is better accounted for not in relation to Left and Right or in relation to modernity, but rather in relation to his perception of the moral links between desire, possession and violence.

Myth

Nous autres Français also foreshadows the link which Girard will later establish between violence and myth. As Bernanos observes, 'Les mythes naissent sous les pas du réaliste, et cet imbécile a tort de s'en étonner, car ils viennent de lui [...] A chaque nouvelle canaillerie des réalistes correspond un mythe qui n'est que la canaillerie elle-même (Bernanos, 1971 [1939b]: 713-4)' For Girard the purpose of myth is especially to mask the real sources of violence when exercised to create or recreate communal unity (1982). Still, by extension, myth is found everywhere in Girard's system; Mensonge romantique et vérité romanesque (1962) explores how the myth of romantic desire (insofar as it depends on a binary system of desiring subject and desired object) had been exposed by a canon of writers who perceived the triangulation of desire. What is key for Girard, however, is that where there is violence, there will always be a myth to disguise its root in mimetic desire.

For Bernanos likewise the perpetrators or advocates of violence show signs of constantly needing the blanket of myth to conceal the sources of their action. Bernanos is so convinced of this that he concludes: 'Le monde sera demain aux mythes' (1971 [1939b]: 718). Bernanos had always denounced, lies but here he perceives a montée des mythes corresponding to the montée aux extrêmes of violence. The application of this principle to Action Française, with all its characteristic violence, was also inevitable. In Nous autres Français, Bernanos remarks quite crushingly: ‘Le pays réel n’a pas de réalité' (1971 [1939b]: $675)$. 
In thus denouncing one of Maurras's favoured depictions of France - le pays réel of the monarchy as opposed to the pays légal of the Republic - Bernanos was only recapitulating the theme of his earlier tract Scandale de la vérité. This tract was originally conceived as a preface to an anthology of texts by Edouard Drumont compiled by Fr Raymond Bruckberger O.P. When the anthology's publication fell through, however, the tract was reworked into publishable form for the Nouvelle Revue française where it appeared in April 1939. It was Bernanos's first opportunity to speak at length about the 1938 Munich pact, about France's part in it, and above all about the actions of Charles Maurras in welcoming the appeasement of Nazi Germany. For Bernanos, in contrast, the betrayal of France's duty to Czechoslovakia represented a grave dishonour. Indeed, the denunciation of this crime was, according to Bernanos, the only truth which could pose a scandal to the postMunich mood of political pragmatism and narrow self-interest.

The word scandal again has Girardian overtones (Girard, 2001) since what is scandalous breaks the illusions created by the myths that are needed to hide the violence of the community. Scandale de la vérité itself is an exercise in the relentless deconstruction of the myths which, Bernanos believed, were essential to the cause of the Maurrassian Right, as to the members of Action catholique and the French hierarchy. In a series of accusations Bernanos fingers their mythic impostures: they treat the temporal domain as if it were the spiritual and vice versa; justice, truth and honour have been used as a veil for self-interest such that their politique too often assumes the just garb of mystique; moreover, he denounces Action Française as an impostor of the true monarchical tradition (Bernanos, 1971 [1939a]: 595-6). For Bernanos, myth seems as omnipresent as incipiently violent desire.

From a Girardian perspective, it is again significant that Bernanos connects his deconstruction of these myths to the redemptive action of Christ who, for Girard (2007 [1978]), exposes the great myth of the persecution of the scapegoat. As for Catholics who 
would mythologize Christianity to serve political ends — arguably, the stock-in-trade of the counterrevolution - Bernanos demands that they stop using Christian revelation possessively as a tool to achieve their own purely human ends:

'Moi, je ne me lasserai pas de répéter à ces gens-là que la vérité ne leur appartient nullement, que la plus humble des vérités a été rachetée par le Christ, qu'à l'égal de n'importe lequel d'entre nous, chrétiens, elle a part à la divinité de Celui qui a daigné revêtir notre nature - consortes ejus divinitatis - entendez-vous, menteurs ?' (1971 [1939a]: 603).

Bernanos here condemns the kind of possessive proprietorship which Girard claims to be the root of all violent conduct, only in this case - and this is crucial — it is Christianity which is doubly sacrificed : first as an object deformed by ideological control, and then by the myth which disguises its manipulation.

Perhaps in this instance we see the convergence of Bernanos's concerns with escalating violence and escalating myth. The burden of Bernanos's témoingage is to challenge his coreligionists and fellow travellers on the Right to embrace truth and renounce the manipulative and violent use of myth: as lies are to power, so truth is to honour, or so Bernanos instinctively felt. From this perspective, his attacks on the Church over Spain are less an expression of freedom of conscience - pace Estève - and more an allegation that Spanish churchmen have not been faithful to their charge. Thus, Bernanos seems to stand before the spectacle of France on the eve of the Second World War, saying - like Steeny glaring at his manipulative mother Michelle and Mademoiselle, her intrusive sidekick 'Menteuse, menteuse' (Bernanos, 1961 [1946]: 1351). 
Sacrificial dynamics in Les Enfants humiliés

As we have argued above, Nous autres Français and Scandale de la vérité can be read in the light of mimetic theory. Among its various themes Nous autres Français clearly rehearses the unfolding of violence inspired by desire, while Scandale de la vérité analyses how the violent generate myths in their defence. We have also argued that the correlations between Bernanos's thought and mimetic theory point to the advantages of a Girardian reading of Bernanos's polemical works when compared to the critical consensus represented by Renard (1998).

Now, these elements in Bernanos's polemical writings, which anticipate so many of Girard's reflections on the origins of violence and the use of myths, find an even more intense realisation in Les Enfants humiliés. Therein, Bernanos's analysis of interwar France, its relations with it military veterans and its conduct towards Germany, depicts a cultural situation that has many correlations with Girard's understanding of the sacrificial mechanisms within human culture. Yet, at the same time, Les Enfants humiliés points to a significant dissonance between Girard's and Bernanos's thinking.

Les Enfants humiliés, like its immediate predecessors, is a short tract with little formal organisation. It is essentially a reflective diary - it is given the subtitle of Journal 1939-1940 - and brings to a head Bernanos's thoughts about France's situation after Munich and before the defeat of June 1940. The text was completed by April 1940 and dedicated to Bernanos's Brazilian friends Mr and Mrs Virgilio de Mello Franco, but it was only published in 1949 a year after Bernanos's death from cancer. Stylistically speaking, it corresponds to the immanent pattern which Renard (1998) rightly detects in the late Bernanos. And yet it sees a dialogue unfold between Bernanos and his own childhood - le petit enfant que je fus, to use his oft repeated expression - which in the contrast it draws between holy enfance and les 
enfants humiliés is a rigorous exercise in the supernatural realism by which light Bernanos analysed all life, fictive or real.

The Girardian elements which emerge from Les Enfants humiliés are very distinct. First, Bernanos's conviction was that France had been stolen from the French, principally by les clercs, the jurists and intellectuals, who had replaced the sentiment of 'la patrie' with the concept of 'l'Etat' (1971 [1949]: 811). The French people were, therefore, the victims of a violent privation before they even had a chance to realise the danger of the rivalry posed by this dangerous elite. Second, those responsible for this theft, alongside la classe dirigeante, appear to Bernanos as the constant aggressors of the French people. The context of the world wars - the memory of the first and the arrival of the second - leads Bernanos to label this group as l'Arrière and himself and his fellow veterans of World War One as l'Avant. Crucially, those who belong to l'Avant are destined to become the scapegoats of the incipient violence which l'Arrière has fomented in the first place. The Girardian overtones here are remarkable:

Car ils savent bien, ils ont dans les moelles la plus veille des traditions religieuses humaines, ils n'ignorent pas que toute purification suppose une préalable expiation, et l'Arrière, sans oser le dire, attend de l'Avant qu'il expie (1971 [1949] : 792, my emphasis).

This sacrificial understanding of the role of the veterans (and indeed of la jeunesse since Bernanos sees the veterans as the young generation who fought 1914-1918) reoccurs throughout the text; whatever happens, it is they who are made to be the scapegoats for the violent crimes committed by les clercs against France; and it is their deaths which help restore order, just as the death of the Girardian scapegoat restores harmony: 
Sur la gigantesque machine à niveler les âmes, on a hissé le pavillon national, et tout ce qu'elle va moudre désormais de médiocrité sera mis au compte de la patrie, débité comme fourniture de guerre (Bernanos, 1971 [1949] : 799).

Clearly, Bernanos's understanding of l'Avant and l'Arrière and of the exploitation of the one by the other foreshadows Girard's explanation of how primitive societies cope with the buildup of internal violence. Instead of seeing in Bernanos's division of the French people from the clerical elite a religiously inspired inflexion of class war theory, we would do better to appreciate how his description of France during this period adumbrates the various agents and processes which characterise Girard's description of the persecution of the scapegoat (1982).

The foreshadowing of the Girardian model of sacrifice is completed by Bernanos through his criticism of the false peace to which this process of expiation leads. In an extended passage on the nature of peace, Bernanos describes the false peace after the expiation of the scapegoat as a kind of lassitude, a state into which people are drawn when they are exhausted by their self indulgence (1971 [1949]: 838). Yet here also - it must clearly be recognised - the Girardian model is not as securely anticipated. The death of Girard's scapegoat refounds societal harmony, even if the death is disguised in myth. For Bernanos, in contrast, this false peace after the expiation of the scapegoat is tangibly an act of imposture and compromise: it is more a 'trêve' than 'la Paix' (1971 [1949]: 837). If we were to explain this dissonance simply by attributing Bernanos's perception of false peace to his sensitivity to myth, we would still fail to explain the almost miraculous power which Girard identifies in the scapegoating process to re-establish societal order. Ultimately, of course, Girard is an anthropologist while Bernanos in his polemical writing is acting principally as a moralist. 
Two further objections should be raised here to the correlations between Bernanos's writing and mimetic theory in Les Enfants humiliés. First, surely Bernanos's celebration of the veterans and his nostalgia for war run clear contrary to Girard's aversion for violence and for the condemnation of violence in mimetic theory. Secondly, Girard's thesis in Achever Clausewitz is that violence is bound to escalate in societies which have jettisoned ancient religious practices for controlling mimetic violence as well as the Christian solution thereto. In reply, it could be argued that Bernanos's celebration of the veterans' honour paradoxically tries to establish at least one value in society which cannot be instrumentalized or reified; one value which, in other words, cannot suffer the violation which mimetic desire would subject it to. Saving the honour of honour, especially perhaps when that honour has been sealed in self sacrifice, remains Bernanos's agenda. Thereby, Bernanos declares invalid all attempts at illicit mimetic appropriation.

In answer to the second objection just noted, it is curious that while Nous autres Français anticipated the violent montée aux extrêmes as described in Girard's Achever Clausewitz, Les Enfants humiliés portray dynamics which Girard would associate with earlier cultural moments. While Bernanos sometimes uses the language of Clausewitz - he describes the wars of the modern state with the Clausewitzian expression 'la guerre de tous contre tous' (1971 [1949]: p. 805) - Les Enfants humiliés evokes what he himself terms 'la plus veille des traditions religieuses humaines'. While Girard has come to believe that the ancient religions, as well as the Christian one, no longer provide a barrier to the escalation of violence, Bernanos seems instead to have arrived at the curious conclusion that the process of war itself can provide for modern France a quasi-religious catharsis. If this points to an undeniable divergence in their appreciation of cultural dynamics within modern France, what cannot be denied is Bernanos's appreciation of the potential of violence in Nous autres Français or his understanding of the dynamics of imitation and their role in explaining the processes of 
human society and culture. It is these processes, rather than any supposed modernity or concession to liberal ideology, which best explain Bernanos's many paradoxes and his unquestionably complex polemical works. And it is indeed his very awareness of the power of mimesis which leads Bernanos (echoing St Jerome) to characterise Satan ultimately as 'le singe de Dieu' (1971 [1949]: 855).

\section{Reservations and conclusions}

There are a range of other objections that could be made to rereading Bernanos's polemical works in a Girardian light. If we contest an analysis of his nostalgia for some far-removed Chrétienté - if for example we ask whether his understanding of the retrieval of the past should not be viewed as a form of eschatology — we must still concede that on his image of the Middle Ages he allowed himself to stencil anachronistically and perhaps unconsciously a person-centred view of freedom. Bernanos himself might have objected to a Girardian reading of his works, not least because he would have deprecated Girard's early aversion to sacrifice in a Christian context (corrected under the influence of Raymund Schwager, 1987 [1978]) and would surely have held in contempt Girard's modernist tendency to make scripture say what he says it means; bizarrely, in Achever Clausewitz, a book purporting to define the Apocalyse, there is very little commentary on The Book of Revelation. It could be argued, furthermore, that Bernanos is guilty of his own violence and myth making, especially in his hounding of the Maurrassian vision of the world and in the way he constructs much of his understanding of the monarchical ideal.

Still, his reason for this is rooted not in some paradoxical inflexion of enlightened individual autonomy, as Renard and Estève believe, but in his commitment to the defence of innocence, and in his sense that violence and myth sacrifice innocence and truth to power. 
The interrelatedness of these themes can serve as a corrective to narrower readings of Bernanos which, for example, would foreground emphatically his role as témoin (Renard, 1994) or his opposition to the modern world (Gosselin and Milner, 1989), arguably at the expense of their relation to this central nexus of Bernanosian themes. Most importantly, their interrelatedness challenges the portrayal of Bernanos as a modern, a portrayal too intent on plotting Bernanos's coordinates against hegemonic social and cultural categories. Bernanos's opposition to totalitarianism and his hatred of liberalism emerge from the same contempt he felt for the varying modes of their possessive aggression towards humanity, and the means by which the powers-that-be of all political stripes sought to veil it in myth.

There is undoubtedly an interiority and subjectivity in Bernanos's last political tracts which sustain a reading of Bernanos as a stylistic moderne. Still, such a paradox has little to say about Bernanos's substantive preoccupation with myth and violence and with his anticipation of the Girardian model of scapegoating in the context of modern France. When these preoccupations are considered, however, it is clear that in his polemical writings on the eve of the Second World War, Georges Bernanos discovers something which René Girard would later attempt to elucidate throughout his theoretical work: that the world can be more accurately interpreted not through its pretexts and justifications, but through its envies and its desires.

\section{References}

Bernanos, Georges (1961) Oeuvres romanesques, ed. by Albert Béguin et al.. Paris, Gallimard, containing the following works referred to in this chapter:

[1936] Journal d'un curé de campagne, 1029-1260.

[1931] La Grande Peur des bien-pensants, 43-350.

[1946] Monsieur Ouine, 1347-1566. 
[1937] Nouvelle Histoire de Mouchette, 1261-1346.

— (1971) Essais et écrits de combat, ed. by Michel Estève et al.. Paris, Gallimard, containing the following works referred to in this chapter:

[1929] Jeanne, relapse est sainte, 19-42.

[1938] Les Grands Cimetières sous la lune, 353-576.

[1939b] Nous autres Français, 615-772.

[1939a] Scandale de la Vérité, 578-613.

[1949] Les Enfants humiliés, 773-905.

Callows, Rebecca, Kovacs, Julia and Rowland Christopher (2004), Revelation: The Apocalypse of Jesus Christ. Oxford, Blackwell Publishing.

Chabot, Jacques (1971) 'Notice sur Nous autres Français' in Essais et écrits de combat, ed. by Michel Estève et al. Paris, Gallimard, 1532-1581.

Delvaux, Paul (1988 Fall-1989 Winter) 'Monsieur Ouine : While awaiting his return ...' Renascence $41: 1 / 2,99-106$.

Daudin, Claire (2009) Dieu a-t-il besoin de l'écrivain? Péguy, Bernanos, Mauriac. Paris, Cerf

Estève, Michel (1994) 'Bernanos et la guerre d'Espagne: le témoin de l'Evangile', Georges Bernanos, témoin, ed. by Pierrette Renard. Toulouse, Presse universitaire du Mirail, $75-86$. 
Girard, René (2007) Achever Clausewitz: Entretiens avec Benoît Chantre. Paris, Carnets Nord.

- (2001) Celui par qui le scandale arrive: Entretiens avec Maria Stella Barberi. Paris, Desclée de Brouwer.

— (2007 [1978]) Des Choses cachées depuis la fondation du monde. Paris, Grasset.

— (2008 [1972]) La Violence et le sacré. Paris, Hachette.

— (1982) Le Bouc émissaire. Paris, Grasset.

- (1961) Mensonge romantique et vérité Romanesque. Paris, Grasset.

Gosselin, Monique and Milner, Max (1989), Bernanos et le monde moderne. Lille, Presses universitaires de Lille.

Greeley, Andrew (2001), The Catholic Imagination. Berkeley, University of California Press.

Lowenthal, David, The Past is a Foreign Country. Cambridge, Cambridge University Press.

Milner, Max (1967) Georges Bernanos. Paris, Desclée de Brouwer.

Renard, Pierrette (1998) 'Les Ecrits de combat et la controverse sur la modernité', Etudes bernanosiennes 21: Bernanos et la modernité, ed. by Michel Estève. Paris, Lettres modernes minard, 73-144.

— (as editor) (1994) Georges Bernanos: témoin. Toulouse, Presse universitaire du Mirail.

Richard, François, (1988) L'Anarchisme de droite dans la littérature contemporaine. Paris, Presses universitaires françaises. 
Storelv, Sven (1993), Péguy, Bernanos, ed. Reidar Veland. Oslo, Solum Forag A/S, containing the following essays referred to in this article:

[1987], 'Bernanos, Discours pamphlétaire et discours apocalyptique', 147156.

[1972] 'Remarques sur le mythe du déclin du monde', 125-138.

Sudlow, Brian (2003) Bernanos's Political Vision: Continuity or Repture in Les Grands Cimetières sous la lune. Nottingham, MA dissertation.

Schwager, Raymund (1987 [1978]), Must There be Scapegoats? Violence and Redemption in the Bible. London, Harper and Row. 